\section{EMULSION LIQUID MEMBRANE FOR HEAVY METALS REMOVAL: EMULSION BREAKING STUDY}

Adhi Kusumastutia*, Samsudin Anisa, A. L. Ahmadb, B. S. Ooib, M. M. H. Shah Buddinc

aFaculty of Engineering, Universitas Negeri Semarang, Kampus UNNES Sekaran, 50229, Semarang, Indonesia bSchool of Chemical Engineering, Engineering Campus, USM, 14300, Nibong Tebal, Penang, Malaysia

cFaculty of Chemical Engineering, Universiti Teknologi MARA, Shah Alam, Selangor 40450, Malaysia
Article history

Received

7 January 2020

Received in revised form

10 July 2020

Accepted

15 July 2020

Published online

27 August 2020

*Corresponding author

adhi_kusumastuti@mail.unnes.ac.id

\section{Graphical abstract}

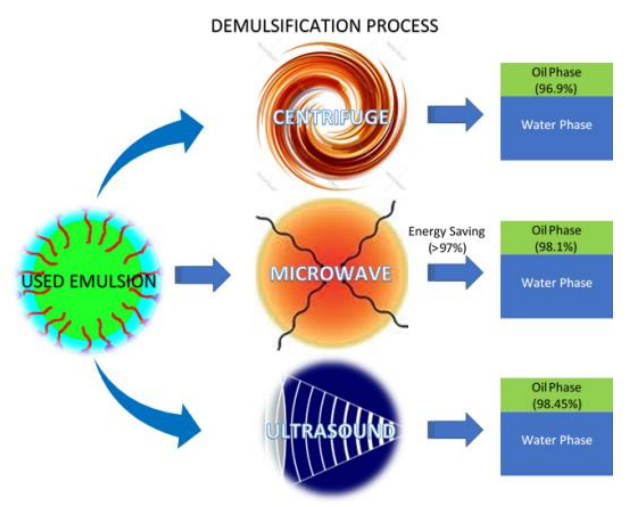

\begin{abstract}
Emulsion liquid membrane (ELM) method has been widely applied in the separation process as the alternative of liquid/liquid extraction. This study compared the application of microwave, ultrasonic probe, and centrifuge in breaking the used emulsion. Demulsification efficiency was investigated in term of water content in the membrane phase solution before and after demulsification. The results showed that the use of microwave to break the used emulsion provided demulsification efficiency of $98.10 \%$, while application of ultrasonic probe was able to break emulsion at efficiency of $98.45 \%$. In the meantime, demulsification efficiency of almost $97 \%$ was achieved when employing centrifuge at centrifugation speed of $3000 \mathrm{rpm}$. Considering the energy consumption, it is recommended to apply microwave irradiation for emulsion breaking. It could save energy up to $97 \%$ and $99 \%$ compared to that of ultrasonic probe and centrifuge, respectively.
\end{abstract}

Keywords: Emulsion liquid membrane, heavy metals, removal, emulsion breaking, demulsification

\begin{abstract}
Abstrak
Kaedah membran cecair emulsi (ELM) telah digunakan secara meluas dalam proses pemisahan sebagai alternatif kepada penyarian cecair-cecair. Kajian ini membandingkan aplikasi gelombang mikro, kuar ultrasonik, dan emparan untuk memecahkan emulsi yang telah digunakan. Kecekapan pengemulsian diselidiki dari segi kandungan air dalam larutan fasa membran sebelum dan selepas demulsifikasi. Keputusan menunjukkan bahawa penggunaan gelombang mikro untuk memecahkan emulsi yang digunakan mencapai kecekapan demulsifikasi 98.10\%, manakala penggunaan kuar ultrasonik telah memecahkan emulsi pada kecekapan $98.45 \%$. Sementara itu, kecekapan demulsifikasi hampir $97 \%$ dicapai apabila menggunakan emparan pada kelajuan $3000 \mathrm{rpm}$. Kaedah gelombang mikro adalah disyorkan untuk memecahkan emulsi disebabkan penggunaan tenaga yang kurang. Penjimatan tenaga untuk demulsifikasi adalah sehingga $97 \%$ bagi kaedah kuar ultrasonik dan $99 \%$ bagi kaedah emparan.
\end{abstract}

Kata kunci: Membran cecair emulsi, logam berat, penyingkiran, pecah emulsi, demulsifikasi 


\subsection{INTRODUCTION}

Emulsion liquid membrane (ELM) is an established technology as a modification of liquid/liquid extraction. ELM has been considered as one of the most attractive type of liquid membrane and more selective than polymer-based membranes [1]. Moreover, most molecules have higher diffusivity through liquids than that of through polymer membranes, leading to higher extraction efficiency [2]. In ELM method, extraction and stripping processes occur in a single step thus make the method economically feasible. ELM involves the mixing of double emulsions, either water in oil in water or oil in water in oil. External phase contains impurities to be extracted. Membrane phase composed of organic solution act as a barrier of external and internal phases. The solute is transferred through the membrane phase towards internal phase $[3,4]$.

ELM system involves three main processes, i.e. emulsification, extraction, and demulsification as illustrated in Figure 1. Emulsion could be produced using blender $[5,6]$, homogenizer $[7,8]$, ultrasonic probe [9, 10], and stirrer [11]. Those researches characterised the produced emulsion in term of emulsion diameter, membrane breakage, and emulsion swelling. The emulsion performance was also tested in the extractions of various impurities.

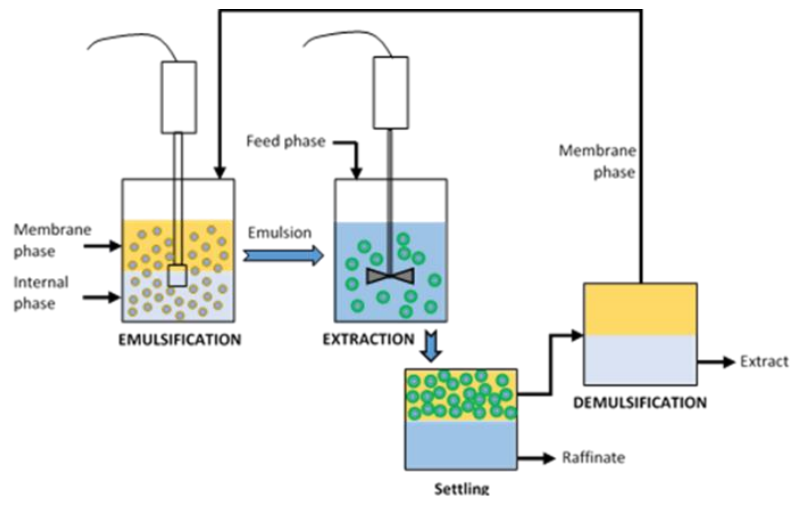

Figure 1 Emulsion liquid membrane process

The ELM method has been widely applied in the separation process. Heavy metal removals using ELM have been intensively studied by many researchers. Cadmium recoveries under ELM system have been investigated by Ahmad, et al. [12], Kumbasar [13], and Mortaheb, et al. [14]. Chromium extractions have been studied by some other researchers [1517]. Other researchers conducted experiments on copper removal by ELM [10, 18, 19]. High concentration of copper is mostly available in the wastewater of many industries such as metallurgy, steel, paper and pulp, fertiliser, and petroleum refining [20]. Beyond the maximum allowable concentration of $1.3 \mathrm{ppm}$, copper is considered as hazardous pollutant. Copper accumulation in animals and humans may cause several disorders of gastroenteritis, diarrhoea, anorexia, dehydration, and shock, while chronic copper poisoning contributes to Alzheimer's, Memkes and Wilson's diseases [21].

The last process in ELM system is demulsification. The used emulsion must be broken that the entrapped solutes could be recovered for further necessities. The liquid membrane and internal phase solution could be reused in the following emulsification process. Emulsion breaking occurs through three steps, i.e. flocculation, coagulation and coalescence. In the first step, flocculation of the dispersed droplets of internal phase occurs, forming some larger groups. Furthermore, the drops in groups coalesce into a large group, leads to the decrease of drops numbers. Finally, due to gravity effect, the large internal drops sink in the interface of membrane and internal phase, coagulate with the water phase, and generate the emulsion breaking [22].

There are several methods of demulsification [23], i.e. chemical demulsification [24, 25], gravity or centrifugal settling [26], $\mathrm{pH}$ adjustment, filtration, heating treatment, electrostatic demulsification [27, 28], and membrane technique [29]. Demulsification process based on the gravity effect occurs in a centrifuge. Centrifugation accelerates sedimentation of an immiscible mixture. Moreover, in the mixtures of solutions in similar densities, gravity separations might take hours. The use of centrifuge could minimise the separation time to be few minutes. Centripetal force could separate greater and lesser density solutions leading to emulsion breaking [26].

Heating has also been used in demulsification, but it is energy-intensive. Emulsion breaking is achieved by applying heat. It has been known that surfactant induces the formation of micelle by interactions of polar hydrophilic head and non-polar hydrophobic tail groups in the mixture. The applied heat interrupts the micelle interactions leading to micelles breakdown and liquids separation. Euston, et al. [30] investigated destabilization of oil in water emulsion by heat induction. They found that large increase of emulsion breakdown occurred at degree of hydrolysis $>27 \%$. Electric field methods have been used to demulsify water-in-oil emulsions [22]. It promotes an irreversible rupturing of the stabilizing emulsions and the droplets coalesce if the external field exceeds a certain critical value. However, it is ineffective for the water-in-oil emulsion having high water content or a swelling. It can produce a "sponge" phase which contains abundant internal aqueous phase in the interface of oil and aqueous phase, so that demulsification efficiency is seriously affected. Another demulsification method is microwave irradiation. This process has similar mechanism with that of dielectric heating. Internal heating occurs when emulsion exposed to electromagnetic field of microwave resulting in molecular rotation and ionic conduction. It is therefore accelerated the emulsion separation process. Chan and Chen [31] investigated the performance of microwave in breaking water in oil 
emulsion by microwave irradiation by testing the effects of emulsion conditions and microwave operating conditions on the demulsification rate and the separation efficiency of W/O emulsion.

In spite of the available reports of emulsion breaking processes through many methods, there is limited articles reveals the comprehensive studies of demulsification in ELM system. Whereas ELM performance also determined by successful demulsification process. This study compared the application of microwave, ultrasonic probe, and centrifuge in breaking the used emulsion. Demulsification efficiency was investigated in term of water content in the membrane phase solution before and after demulsification.

\subsection{METHODOLOGY}

\subsection{Materials}

The aqueous copper solutions were prepared by dissolving copper nitrate (Merck) in deionised water. $\mathrm{HCl}$ (Merck) was added to the feed solution to adjust the $\mathrm{pH}$. Trioctylamine (Merck) and Span 80 (Merck) were used as extractant and surfactant, respectively. Low odour kerosene purchased from Sigma Aldrich was used as diluent. Ammonia (Merck) was used as internal phase solution.

\subsection{Procedures}

After the extraction process, the organic membrane phase was recovered for its diluents. The demulsification processes using physical treatment process were applied. The water content in the emulsion before demulsification and in the membrane phase after demulsification was measured. The demulsification efficiency $(\mathrm{Br})$ was calculated as:

$$
\mathrm{Br}=\frac{\theta_{0}-\theta_{1}}{\theta_{0} \times\left(1-\theta_{1}\right)} \times 100 \%
$$

$\mathrm{Br}$ refers to demulsification efficiency, $\theta_{0}$ is the fraction of water content in the emulsion before demulsification, and $\theta_{1}$ is the fraction of water content in the membrane phase after demulsification. Energy consumption $\left(E_{c}\right)$ for emulsion breaking was determined as:

$$
E_{c}=P_{\text {in }} x t
$$

where $P_{\text {in }}$ is the power consumed $(\mathrm{J} / \mathrm{s})$ and $t$ is the demulsification time (s).

\subsubsection{Microwave Demulsification}

A beaker glass was used to collect used emulsion. It was then placed in defined position in the microwave (domestic microwave oven, Panasonic, NN-SM330 M) thus every experiment got the same heating irradiation. Experiments were done at irradiation power of $50 \mathrm{~W}, 380 \mathrm{~W}, 540 \mathrm{~W}$, and $700 \mathrm{~W}$ for $8 \mathrm{~s}, 10 \mathrm{~s}, 12 \mathrm{~s}$, and $15 \mathrm{~s}$ irradiation time. The irradiated sample was settled down until 15 minutes and then collected for water content analysis.

\subsubsection{Ultrasound Demulsification}

Used emulsion was placed in a beaker glass. The 22.5 $\mathrm{kHz}$ ultrasonic irradiation (Ultrasonic USG-150) equipped with a titanium horn (3 $\mathrm{mm}$ diameter) was mounted at the top of the cylindrical glass cell. The emulsion was treated for 2, 4, 8, and 10 minutes at a frequency of $20 \mathrm{kHz}$ in different intensities of about $20 \%, 60 \%$, and $80 \%$. Water content analysis was also done to the demulsified samples.

\subsubsection{Centrifuge Demulsification}

Certain volume of the used emulsion was put in the centrifuge bottle. The demulsifying method was conducted in a centrifuge (Kubota 5220) that accelerates the sedimentation at 2500-3500 rpm. The centrifugation time was varied from 5 to 15 minutes with interval of 5 minutes. After centrifugation process, the organic sample on the top layer of the solution is collected for water content analysis.

GC-MS analysis by using a Perkin Elmer GC Clarus 680 MS Clarus SQ 8T was also applied to identify the organic membrane phase after demulsification. The length of column is $30 \mathrm{~m}$ with $250 \mu \mathrm{m}$ of diameter. Maximum temperature of oven was set at about $300^{\circ} \mathrm{C}$. Helium was used as carrier gas with $0.8 \mathrm{ml} / \mathrm{min}$ of flow rate. The sample was filtered by using a filter paper before injected into the GC at one $\mu$ l.

\subsection{RESULTS AND DISCUSSION}

\subsection{Microwave Demulsification}

The used emulsion needs to be broken so that membrane component can be reused for further emulsification process. After demulsification, the clear upper layer was sampled; pure kerosene indicated the success of demulsification process. The water content was then tested and the efficiency was calculated using Equation 1. Study of Henry [32] found that microwave irradiation was effective in reducing emulsion stability at relatively high water separation efficiency. It was also revealed that at equal irradiation exposure time and power, emulsion with higher water content achieved better demulsification efficiency. This is due to the nature properties of water, in which energy absorption of water is higher than that of oil. Figure 1 shows the effects of both microwave irradiation and settling time on demulsification efficiency. It is seen that demulsification efficiency increase with the increase of irradiation and settling time. Right after separation at irradiation time of $8 \mathrm{~s}$, almost no separation of 
water and oil phase occurred thus resulted in very low demulsification efficiency. Significant increase of demulsification efficiency was seen after prolonging settling times. Increment of demulsification rate by the increase of microwave irradiation time is affected by dielectric heating properties that able to separate water-in-oil emulsions. The highest demulsification efficiency of $82.45 \%$ was achieved by applying irradiation time of $15 \mathrm{~s}$ and settling time of $15 \mathrm{~min}$.

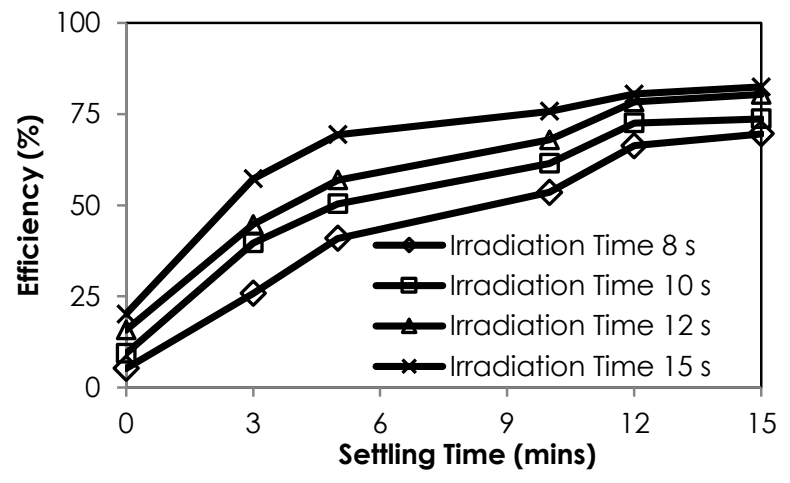

Figure 1 Demulsification efficiency (Microwave power 540 W; Irradiation time: $8,10,12$, and $15 \mathrm{~s}$; settling time: $0,3,5$, $10,12,15$ mins)

Figure 2 reveals that very small amount of aqueous phase can be separated with a $50 \mathrm{~W}$ power output. Even with power output above $380 \mathrm{~W}$, a critical settling time greater than 5 min was necessary to give significant raise in demulsification rate. Along with settling time, demulsification rate increases with the increase of microwave power. The increase of microwave irradiation power resulted in higher separation efficiency as well as sample temperature. Improvement of microwave irradiation power from $50 \mathrm{~W}$ to $380 \mathrm{~W}$ gave insignificant effect of demulsification efficiency. Neither did further improvement to 540 W. Mohammed and Mohammed [33] found that this phenomenon was triggered by the increase of wavelength and penetration depth as the increase of microwave power.

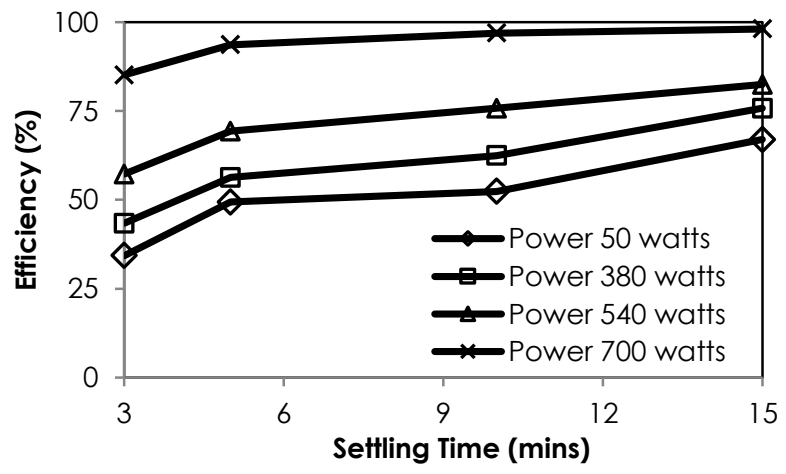

Figure 2 Demulsification efficiency (Irradiation time: $15 \mathrm{~s}$; Microwave power 50, 380, 540, and $700 \mathrm{~W}$ )

\subsection{Ultrasound Demulsification}

Among the important factors affecting emulsions breaking is sound intensity. In which, energy level is varied depend on the sound intensities given to emulsions. Dehydration process of emulsions is only determined by mechanical effects of ultrasound. It was revealed that the increment of sound intensity resulted in the lower emulsion water content [34]. They found that the lowest water content was achieved at sound intensity of $0.66 \mathrm{~W} / \mathrm{cm} 2$, further increase in sound intensity actually increased water content. This also applies in this study, where sound intensity of $60 \%$ resulted in the best demulsification efficiency, shown in Figure 3. This is due to higher sound intensity triggered the reduction of water-oil interface tension leading to emulsion breaking. However, further increment of sound intensity to be $80 \%$ leading to the decrease of demulsification efficiency. This is because excessive sound intensity caused re-emulsification phenomenon [34].

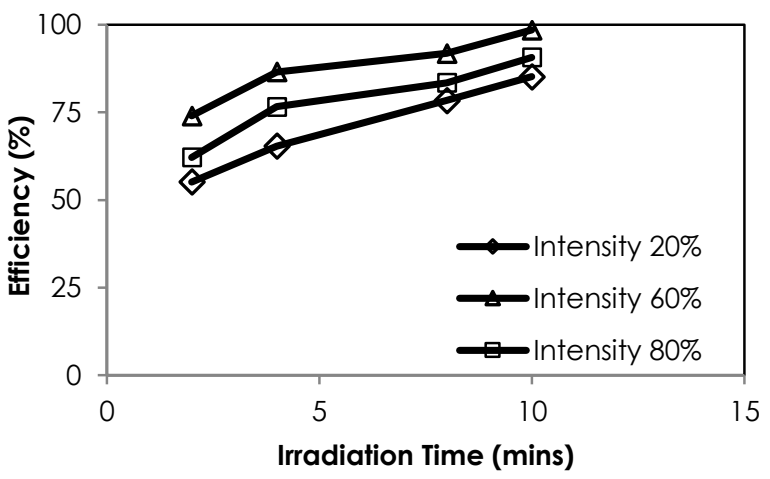

Figure 3 Demulsification efficiency (Intensity: 20\%, 60\%, and $80 \%$; Irradiation time: $2,4,8,10 \mathrm{~min}$ )

\subsection{Centrifuge Demulsification}

Demulsification under centrifuge force was investigated in terms of time and speed. To see the compounds, some of the samples were tested using GC-MS. The demulsification results are presented in Figure 4.

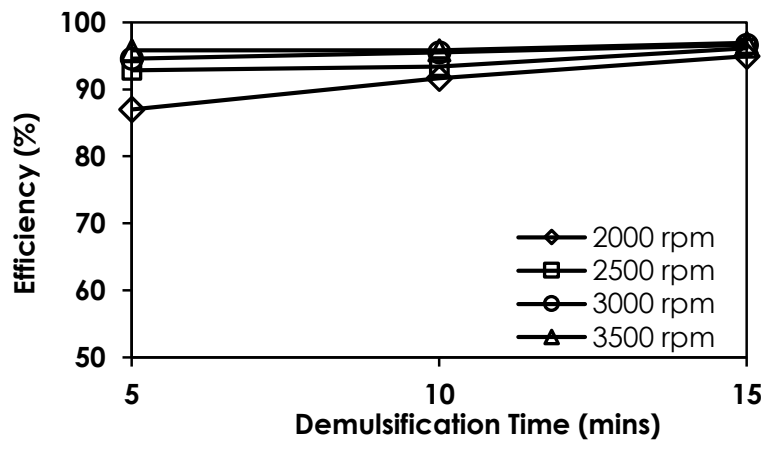

Figure 4 Demulsification efficiency (centrifugation speed: 2000, 2500, 3000, and 3500 rpm; centrifugation time: 5, 10 , and $15 \mathrm{~min}$ ) 
It is revealed in Figure 4 that due to the principles of gravity separation, increasing centrifugation speed could enhance demulsification efficiency. Each phase is separated due to the density difference between each phase. Higher centrifugation speed as well as longer centrifugation time is able to accelerate the separation process. The graph also shows that at centrifugation speed of $2000 \mathrm{rpm}$, efficiency was governed by time. At 5 min, efficiency was only about $86 \%$, it gradually increased to be $90 \%$ at $10 \mathrm{~min}$, and at the end of the process it succeeded to reach $92 \%$. On the contrary, at high centrifugation speed of $3500 \mathrm{rpm}$, there was no significant increase in efficiency with the time extension. At 5,10 , and 15 min of demulsification process, the efficiencies were about $96 \%$. It is also seen that at $15 \mathrm{~min}$, demulsification efficiency increased from $95 \%$ at $2000 \mathrm{rpm}$ to be $97 \%$ at 3500 rpm.

GC-MS testing was done and intended to verify the compounds in the organic membrane phase after demulsification process, which consists of kerosene as a diluent and TOA as a carrier. For this reason, the membrane phase obtained from centrifuge demulsification process was selected and used as the sample. In general, there were about 20 major compounds of total ion chromatogram (TIC) detected qualitatively from the organic membrane phase sample. GC-MS result for each centrifugation speed was revealed in Figures 5-8. The figures define that in retention time of 5-15 min, kerosene compounds were exclusively detected. TOA was detected at around $21 \mathrm{~min}$ and after $25 \mathrm{~min}$ of retention time for centrifugation speeds above and below 3000 rpm, respectively.

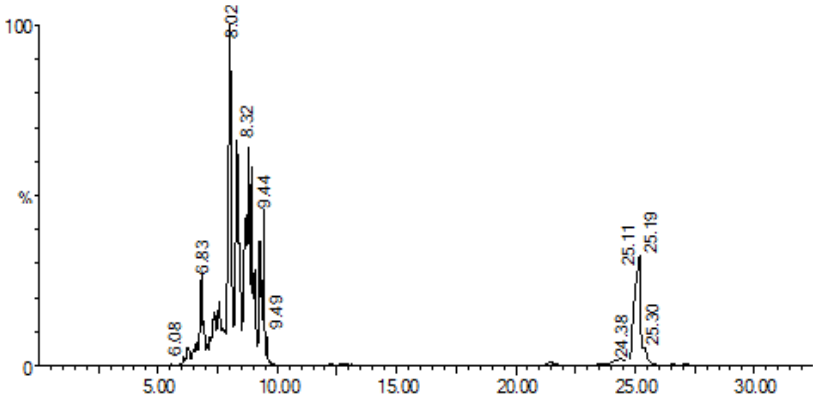

Figure 5 Demulsification efficiency (Total ion chromatogram of demulsification process at $2000 \mathrm{rpm}$ )

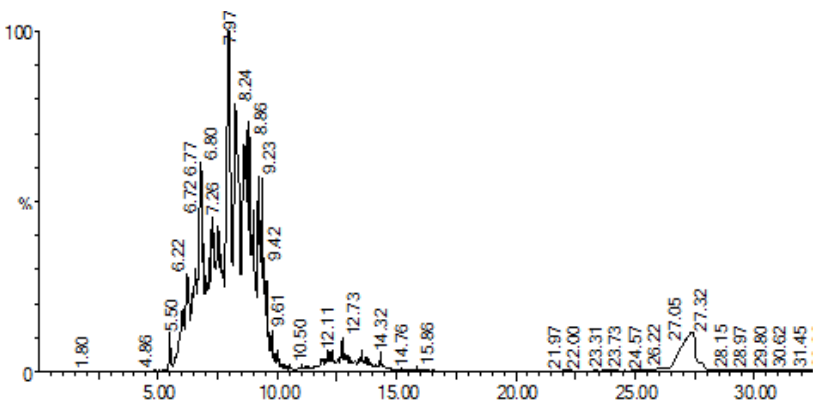

Figure 6 Demulsification efficiency (Total ion chromatogram of demulsification process at $2500 \mathrm{rpm}$ )

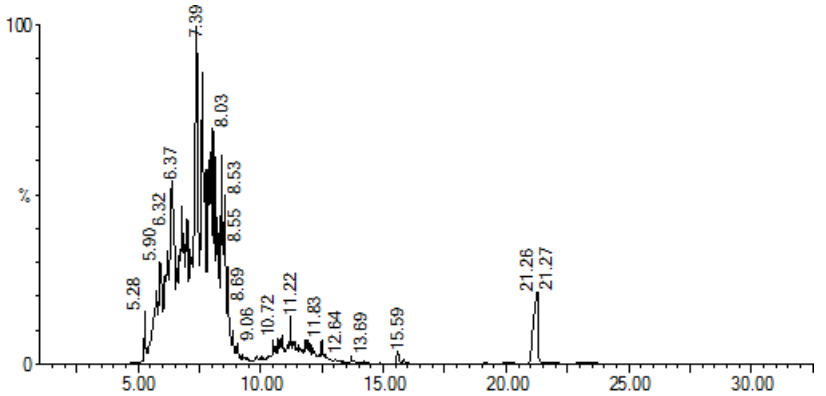

Figure 7 Demulsification efficiency (Total ion chromatogram of demulsification process at $3000 \mathrm{rpm}$ )

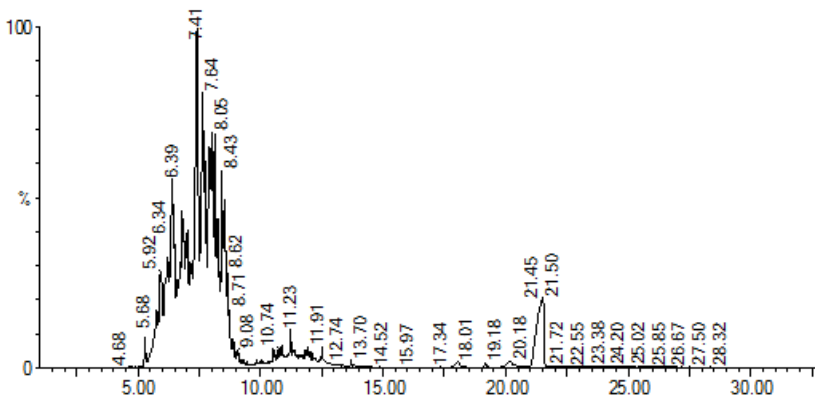

Figure 8 Demulsification efficiency (Total ion chromatogram of demulsification process at $3500 \mathrm{rpm}$ )

The increase of centrifugation speed from 2000 rpm to $3500 \mathrm{rpm}$ enabled the system to demulsify and to recover almost all of kerosene and TOA. It was indicated from total ion chromatogram report that demulsification process was able to recover about $99 \%$ and $98.7 \%$ of TOA and kerosene in organic membrane phase for $3500 \mathrm{rpm}$ and $3000 \mathrm{rpm}$, respectively. Whereas at $2000 \mathrm{rpm}$, less than $90 \%$ of kerosene and TOA was able to be recovered while at $2500 \mathrm{rpm}$, more kerosene and TOA of about $97 \%$ was recovered.

\subsection{Demulsification and Energy Consumption Assessment}

Demulsification processes done by microwave, ultrasound, and centrifuge have been completed. Comparison of each process is described in Figure 9. It is seen that demulsification efficiency was in the order of ultrasound > microwave > centrifuge. However, there was no significant difference of demulsification efficiency of each mode. In term of energy consumption, there was tremendous difference of each demulsification tool. Microwave provided the most energy efficient demulsification process. In this case, microwave demulsification only used $16.875 \mathrm{~kJ}$ of energy or about 117 times lower than that of centrifuge. While ultrasound, required energy of about $600 \mathrm{~kJ}$, was higher than that used of microwave. The highest energy of 1980 kJ was applied in centrifuge demulsification. It is therefore, 
microwave demulsification is the most recommended process.

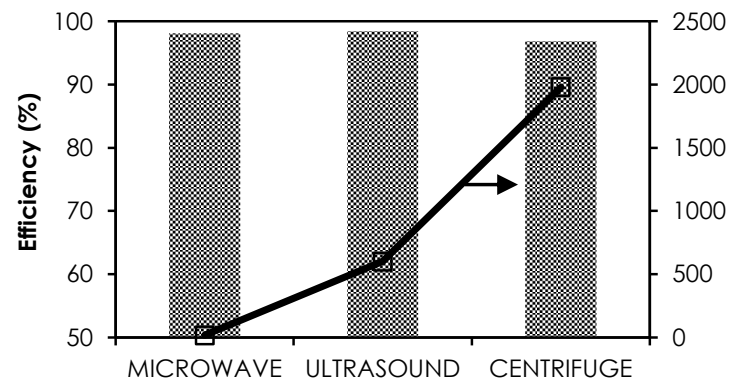

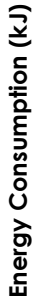

Figure 9 Comparison of demulsification efficiency and energy consumption for each demulsification equipment

\subsection{CONCLUSION}

Laboratory experiment showed the application of microwave, ultrasonic probe, and centrifuge for emulsion breaking. All the demulsification tools were successfully applied to break the used emulsion based on their specific operation condition. In general, demulsification efficiencies of above $97 \%$ were obtained. It was found that the order of demulsification efficiency was centrifuge < microwave < ultrasound. Although ultrasound provided the highest demulsification efficiency, it consumed more energy. Among the demulsification tools, microwave demulsification involved the lowest energy consumption. The significant difference of energy consumption was also supported by almost the same demulsification efficiency. So that, considering the economics of overall emulsion liquid membrane process, microwave irradiation is highly recommended for breaking the used emulsion. It should be noted that the water in the sample absorbs microwave energy, resulting in heating due to polarization of water molecules, leading to the acceleration of the demulsification process. In this study, 15 seconds of irradiation time was enough to break the emulsion at high efficiency.

\section{Acknowledgement}

Fundamental research grant from Ministry of Research, Technology, and Higher Education of Indonesia is gratefully acknowledged.

\section{References}

[1] Kumar, A., Thakur, A. and Panesar, P. S. 2019. A Review on Emulsion Liquid Membrane (ELM) for the Treatment of Various Industrial Effluent Streams. Reviews in Environmental Science and Bio/Technology. 18(1): 153182.

DOI: $10.1007 / \mathrm{s} 11157-019-09492-2$
[2] Chakraborty, M., Bhattacharya, C. and Datta, S. 2010. Chapter 4 - Emulsion Liquid Membranes: Definitions and Classification, Theories, Module Design, Applications, New Directions and Perspectives. Liquid Membranes. S. K. Vladimir, Editor. Elsevier: Amsterdam. 141-199.

[3] Ahmad, A. L., Kusumastuti, A., Derek, C. J. C., \& Ooi, B. S. 2011. Emulsion Liquid Membrane for Heavy Metal Removal: An Overview on Emulsion Stabilization and Destabilization. Chemical Engineering Journal. 171 (3): 870882.

DOI: https://doi.org/10.1016/j.cej.2011.05.102.

[4] Kislik, V., ed. 2009. Liquid Membranes: Principles and Applications in Chemical Separations and Wastewater Treatment. Elsevier Science: Amsterdam.

[5] Sengupta, B., Sengupta, R. and Subrahmanyam, N. 2006. Process Intensification of Copper Extraction Using Emulsion Liquid Membranes: Experimental Search for Optimal Conditions. Hydrometallurgy. 84(1-2): 43-53. DOI: https://doi.org/10.1016/j.hydromet.2006.04.002.

[6] Sengupta, B., Sengupta, R. and Subrahmanyam, N. 2006. Copper Extraction into Emulsion Liquid Membranes using

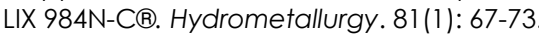

DOI: https://doi.org/10.1016/j.hydromet.2005.10.002

[7] Chakraborty, M., Bhattacharya, C. and Datta, S. 2003. Effect of Drop Size Distribution on Mass Transfer Analysis of the Extraction of Nickel(II) by Emulsion Liquid Membrane. Colloids and Surfaces A: Physicochemical and Engineering Aspects. 224(1-3): 65-74 DOI: https://doi.org/10.1016/S0927-7757(03)00260-7.

[8] Sahoo, G. C. and Dutta, N. N. 1998. Studies on Emulsion Liquid Membrane Extraction of Cephalexin. Journal of Membrane Science. 145(1): 15-26. DOI: https://doi.org/10.1016/\$0376-7388(98)00027-1.

[9] Ahmad, A. L., Kusumastuti, A., Derek, C. J. C., \& Ooi, B. S. 2012. Emulsion Liquid Membrane for Cadmium Removal: Studies on Emulsion Diameter and Stability. Desalination. 287: 30-34.

DOI: https://doi.org/10.1016/j.desal.2011.11.002.

[10] Chiha, M., Hamdaovi, O., Ahmedchekkat, F., \& Pétrier, C. 2010. Study on Ultrasonically Assisted Emulsification and Recovery of Copper(II) from Wastewater Using an Emulsion Liquid Membrane Process. Ultrasonics Sonochemistry. 17(2): 318-325. DOI: https://doi.org/10.1016/j.ultsonch.2009.09.001.

[11] Mousavi, S. M., Kiani, S., Farmad, M. R., Hemati, A., \& Abbasi, B. 2012. Extraction of Arsenic(V) from Water Using Emulsion Liquid Membrane. Journal of Dispersion Science and Technology. 33(1): 123-129.

DOI: http://doi.org/10.1080/01932691.2010.548230.

[12] Ahmad, A. L., Kusumastuti, A., Derek, C. J. C., \& Ooi, B. S. 2013. Emulsion Liquid Membranes for Cadmium Removal: Studies of Extraction Efficiency. Membrane Water Treatment. 4(1): 15. DOI: 10.12989/mwt.2013.4.1.011.

[13] Kumbasar, R. A. 2009. Extraction and Concentration Study of Cadmium from Zinc Plant Leach Solutions by Emulsion Liquid Membrane Using Trioctylamine as Extractant. Hydrometallurgy. 95(3-4): 290-296. DOI: https://doi.org/10.1016/j.hydromet.2008.07.001

[14] Mortaheb, H. R., Kosuge, H., Mokhtarani, B., Amini, M. H., \& Banihashemi, H. R. 2009. Study on Removal of Cadmium from Wastewater by Emulsion Liquid Membrane. Journal of Hazardous Materials. 165(1-3): 630-636. DOI: https://doi.org/10.1016/j.jhazmat.2008.10.039.

[15] García, M. G., Acosta, A. O. and Marchese, J. 2013. Emulsion Liquid Membrane Pertraction of $\mathrm{Cr}(\mathrm{III})$ from Aqueous Solutions Using PC-88A as Carrier. Desalination. 318(0): 88-96. DOl: http://dx.doi.org/10.1016/j.desal.2013.03.025.

[16] Goyal, R. K., Jayakumar, N. S. and Hashim, M. A. 2011. Chromium Removal by Emulsion Liquid Membrane Using [BMIM]+[NTf2]-as Stabilizer and TOMAC as Extractant. Desalination. 278(1-3): 50-56.

DOI: https://doi.org/10.1016/j.desal.2011.05.001. 
[17] Zhao, L., Fei, D., Dang, Y., Zhou, X., \& Xiao, J. 2010. Studies on the Extraction of Chromium(III) by Emulsion Liquid Membrane. Journal of Hazardous Materials. 178(1-3): 130135. DOI: http://dx.doi.org/10.1016/j.jhazmat.2010.01.052.

[18] Valenzuela, F., Araneda, C., Vargas, F., Basualto, C., \& Sapag, J. 2009. Liquid Membrane Emulsion Process for Recovering the Copper Content of a Mine Drainage. Chemical Engineering Research and Design. 87(1): 102108.

DOI: https://doi.org/10.1016/j.cherd.2008.05.010.

[19] Sengupta, B., Bhakhar, M. S. and Sengupta, R. 2009. Extraction of Zinc and Copper-zinc Mixtures from Ammoniacal Solutions into Emulsion Liquid Membranes using LIX 84|®. Hydrometallurgy. 99(1-2): 25-32. DOI: https://doi.org/10.1016/j.hydromet.2009.05.021.

[20] Tofighy, M. A. and Mohammadi, T. 2011. Adsorption of Divalent Heavy Metal Ions from Water Using Carbon Nanotube Sheets. J Hazard Mater. 185(1): 140-7.

[21] Strausak, D., Mercer, J. F. B., Dieter, H. H., Stremmel, W., \& Multhaup, G. 2001. Copper in Disorders with Neurological Symptoms: Alzheimer's, Menkes, and Wilson Diseases. Brain Research Bulletin. 55(2): 175-185. DOI: https://doi.org/10.1016/S0361-9230(01)00454-3.

[22] LU, G., Lu, Q. and Li, P. 1997. Break-down of Liquid Membrane Emulsion Under High Electric Field. Journal of Membrane Science. 128(1): 1-6. DOI: http://dx.doi.org/10.1016/S0376-7388(96)00298-0.

[23] Zolfaghari, R., Fakhru'l-Razi, A., Luaman Chuah, A., S. E. H. Elnashaie, S., \& Pendashteh, A. 2016. Demulsification Techniques of Water-in-Oil and Oil-in-Water Emulsions in Petroleum Industry. Separation and Purification Technology. 170(0): 377-407.

DOI: https://doi.org/10.1016/j.seppur.2016.06.026.

[24] Azizi, K. and Nikazar, M. 2015. Characterization of Chemical Demulsification of Oil in Water Emulsion: Comparison Between a Kinetics Model and Laboratory Experiments. Petroleum Science and Technology. 33(1): 814.

DOI: https://doi.org/10.1080/10916466.2014.940088.

[25] Balsamo, M., Erto, A. and Lancia, A. 2017. Chemical Demulsification of Model Water-in-Oil Emulsions with Low Water Content by Means of Ionic Liquids. Brazilian Journal of Chemical Engineering. 34(1): 273-282.

DOI: $\quad$ http://dx.doi.org/10.1590/0104-

$6632.20170341 \mathrm{~s} 20150583$.
[26] Nour, A. H., Mohammed, F. S., Yunus, R. M., \& Arman, A. 2009. Demulsification of Virgin Coconut Oil by Centrifugation Method: A Feasibility Study. International Journal of Chemical Technology. 1: 59-64. DOI: https://doi.org/10.3923/ijct.2009.59.64.

[27] Mhatre, S., Vivacqua, V., Ghadiri, M., Abdullah, A. M., AlMarri, M. J., Hassanpour, A., Hewakandamby, B., Azzopardi, B. \& Kermani, B. 2015. Electrostatic Phase Separation: A Review. Chemical Engineering Research and Design. 96(0): 177-195.

DOI: https://doi.org/10.1016/j.cherd.2015.02.012.

[28] Othman, N., Tan, K. S., Noah, N. F. M., Ooi, Z. Y., Norela Jusoh, \& Nasruddin, N. A. 2015. Performance of Electrostatic Field in Continuous Demulsification of Simulated Crude Oil Emulsion. Jurnal Teknologi. 74(7): 9398.

DOI: https://doi.org/10.11113/jt.v74.4705.

[29] Wu, J., Wei, W., Li, S., Zhong, Q., Liu, F., Zheng, J., \& Wang, J. 2018. The Effect of Membrane Surface Charges on Demulsification and Fouling Resistance During Emulsion Separation. Journal of Membrane Science. 563(0): 126133. DOI: https://doi.org/10.1016/j.memsci.2018.05.065.

[30] Euston, S. R., Finnigan, S. R. and Hirst, R. L. 2001. HeatInduced Destabilization of Oil-in-Water Emulsions Formed from Hydrolyzed Whey Protein. Journal of Agricultural and Food Chemistry. 49(11): 5576-5583. DOI: https://doi.org/10.1021/jf0102620.

[31] Chan, C.-C. and Chen, Y.-C. 2002. Demulsification of W/O Emulsions by Microwave Radiation. Separation Science and Technology. 37(15): 3407-3420.

DOI: https://doi.org/10.1081/ss-120014434.

[32] Henry, N. E. 2013. Effects of Microwave Irradiation on the Characteristics of Water-Oil Emulsions. Petroleum Engineering. Master. Nova Scotia: Dalhousie University.

[33] Mohammed, S. A. M. and Mohammed, M. S. 2013. The Application of Microwave Technology in Demulsification of Water-in-Oil Emulsion for Missan Oil Fields. Iraqi Journal of Chemical and Petroleum Engineering. 14(2): 21-27.

[34] Sun, L., Han, P., Yang, L., \& Lu, X. 2014. The Dehydration and Demulsification of Waste Oil by Ultrasound. Energy Sources, Part A: Recovery, Utilization, and Environmental Effects. 36(17): 1843-1849.

DOI: https://doi.org/10.1080/15567036.2011.551921. 